\title{
EFFECT OF SEASON ON HORMONALLY INDUCED OVULATION IN MERINO EWES
}

\author{
D. R. LAMOND \\ C.S.I.R.O. Division of Animal Physiology, Pastoral Research Laboratory, Armidale, \\ New South Wales, Australia
}

(Received 8th December 1961)

Summary. An experiment was carried out to obtain quantitative information on time of ovulation after hormonal treatments at four times of the year. Four groups of Merino ewes were used in a $4 \times 2 \times$ $3 \times 2$ factorial experiment, the factors being:

(a) Four times in one year: July 1960, October 1960, January 1961, April 1961.

(b) Two doses of PMs: 300 i.u., 900 i.u.

(c) Three doses of HGG: 300 i.u., 600 i.u., 1200 i.u.

(d) Administration of HCG at two different periods after PMs: $24 \mathrm{hr}$, $48 \mathrm{hr}$.

All ewes were given $12.5 \mathrm{mg}$ of progesterone in oil every 2 days for 2 weeks. PMS was given at the time of the final injection of progesterone. The time of ovulation was determined at laparotomy at various periods after the final hormone injection.

There were no significant differences between times of year in either number of ovulations occurring during progesterone treatments or in numbers of multiple ovulations following cessation of hormone treatments.

Seasonal differences in numbers of ewes not ovulating and in the time of ovulation in the remainder were observed.

The results cannot be explained by a simple theory of seasonality in ovulating hormone production, but point to a more fundamental problem of a neuro-hormonal nature.

\section{INTRODUCTION}

In addition to cessation of oestrous cycles during spring and early summer (see reviews by Robinson, 1951; Hafez, 1952) seasonal differences in reproductive function in the ewe are manifest in ovulation rates (Grant, 1934; McKenzie \& Terrill, 1937; Hammond, Jnr., 1944; Morley, 1948; Watson, 1952; Averill, 1955, 1959; Hunter, 1959; Radford, 1959; Dun, Ahmed \& Morrant, 1960); length of oestrus (McKenzie \& Terrill, 1937); length of oestrous cycles (Hammond, Jnr., 1944); incidence of oestrus after introduction of rams (Riches \& Watson, 1954; Dun et al., 1960); and embryonic 
losses (Dutt, 1951; Hulet, Voigtlander, Pope \& Casida, 1956; Laffey \& Hart, 1959).

The underlying neural and hormonal basis for these seasonal phenomena have not been elucidated. Seasonal differences have been observed in amounts of oestrogen which must be given to ovariectomized ewes, following progesterone priming, to induce oestrus (Raeside \& McDonald, 1959; Reardon \& Robinson, 1961). Lamond (1961) and Lamond \& Bindon (1962) have observed that the period from cessation of progesterone suppressive (breeding season) injections to onset of oestrus, varies with time of year. Bioassays of gonadotrophins in sheep anterior pituitary glands (which, however, do not provide conclusive evidence of secretory function) have given variable results. Some authors have been unable to detect the postulated (Robinson, 1951) seasonal decline in gonadotrophin content during anoestrus (Warwick, 1946; Kammlade, Welch, Nalbandov \& Norton, 1952; Lamond, Radford \& Wallace, 1959; Hutchinson \& Robertson, 1960). On the other hand, Raeside \& Lamond (1956) obtained an increase in potency a few weeks prior to the onset of the breeding season and Clegg \& Ganong (1960) found that pituitary luteinizing hormone (LH) levels were lower during anoestrus than during the breeding season.

With an indirect method, Lamond (1960) adduced evidence pointing to secretion of less ovulating hormone during anoestrus than during the breeding season. This was based on the time of ovulation in progesterone-treated ewes given pregnant mare's serum gonadotrophin (PMS) and human chorionic gonadotrophin (HCG). The present paper describes a factorial experiment that was carried out to obtain quantitative information on time of ovulation after hormonal treatment at four times of the year.

\section{MATERIALS AND METHODS}

EXPERIMENTAL DESIGN

Ewes were injected with $12.5 \mathrm{mg}$ of progesterone every 2 days for 13 days (seven injections). On the day of the final injection, PMs was administered subcutaneously, followed 24 or $48 \mathrm{hr}$ later by an intramuscular injection of HCG. The ewes were subjected to laparotomy approximately 22,32 and $45 \mathrm{hr}$ after HCG. The treatment schedule is outlined in Table 1. With fresh ewes each time, the experiment was carried out four times at 3-monthly intervals. The experimental design was therefore a $4 \times 2 \times 3 \times 2$ factorial with four ewes per group, as follows:

(a) Four times of the year: July 1960, October 1960, January 1961, April 1961.

(b) Two dosage levels of PMs: 300 i.u., 900 i.u.

(c) Three dosage levels of HCG: 300 i.u., 600 i.u., 1200 i.u.

(d) Administration of HCG at two different periods after PMs: $24 \mathrm{hr}, 48 \mathrm{hr}$. The four times of the year represent well-defined stages of the breeding season (see Text-fig. 1 for details of breeding seasons in sheep at the Pastoral Research Station, Armidale). Thus May to June is generally the middle of the breeding season and November to January is the anoestrous period. April, 
therefore, represents a period when oestrous activity approaches its maximum; July, when oestrous activity begins to decline; October, when anoestrus may be expected to have commenced in some ewes; and January, when the anoestrous period may be expected to be ending. The times selected, therefore, represent periods of change rather than peaks or troughs in breeding activity.

TABLE 1

INJEGTION AND LAPAROTOMY SGHEDULE

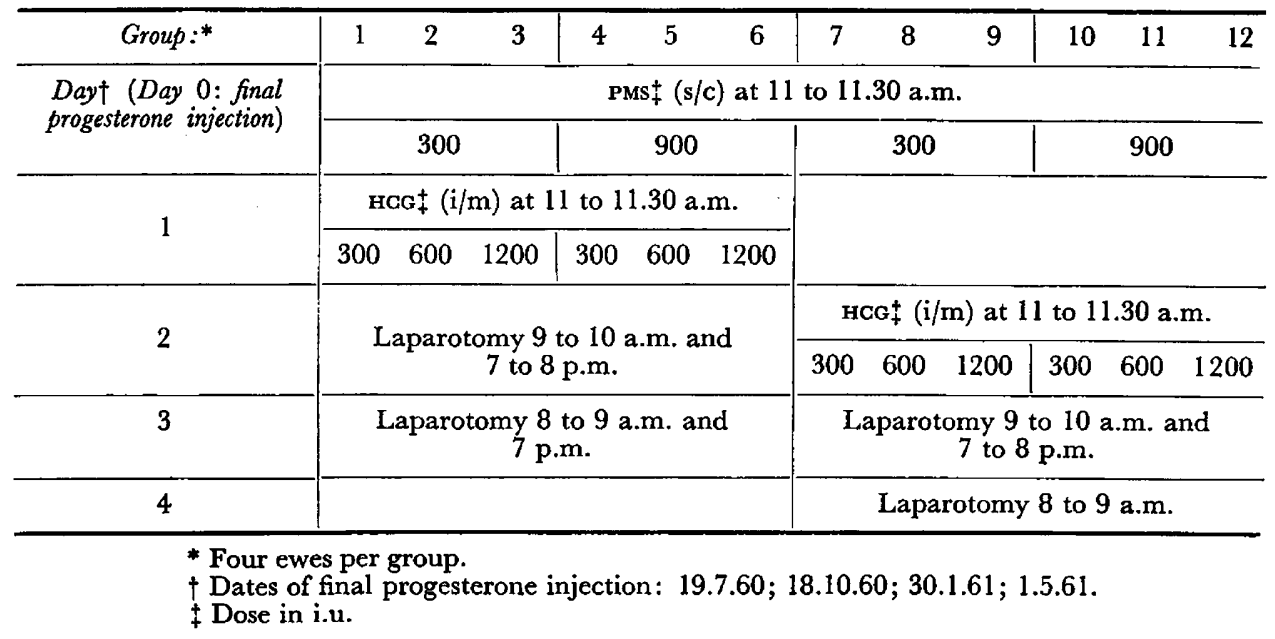

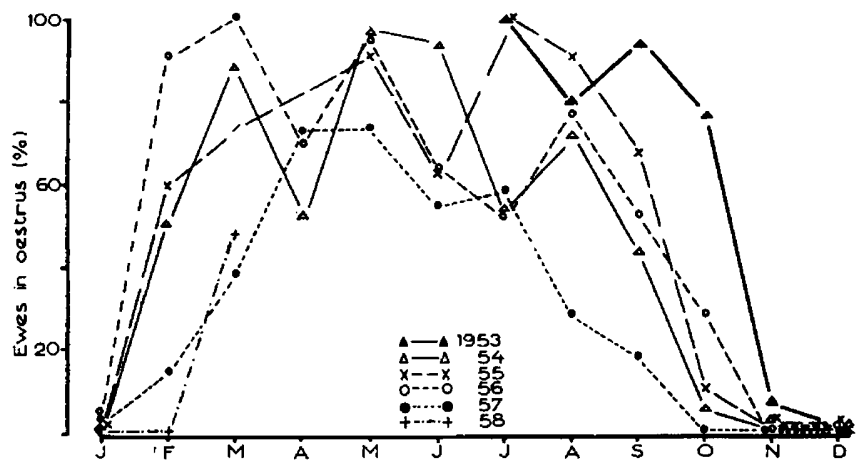

Text-Fig. 1. Percentage of ewes in oestrus each month over a 5-year period. Data from Barrett, Reardon \& Lambourne (1962) for thirty-five ewes run continuously with vasectomized rams at the C.S.I.R.O. Pastoral Research Station, Armidale.

\section{ANIMALS}

One hundred and ninety-six non-lactating 3- to 5-year-old Merino ewes, all of which had lambed previously, were randomly allotted to four groups of forty-eight in July 1960. One group, the July group, was yarded and the remainder returned to pasture. Ewes in yards received a grain-chaff maintenance ration. Those at pasture did not receive supplements at any time. 
Seasonal conditions were dry but the body condition of the ewes remained fairly constant throughout. Pastures were mainly native grasses improved with Trifolium repens (white clover) and Phalaris tuberosa. The ewes at pasture were not exposed to oestrogen-containing pasture as far as is known (Southcott, Braden \& Moule, unpublished data). Shearing normally takes place in November hence the amount of fleece the ewes carried was July -8 months, October - 11 months, January -2 months, and April -5 months growth.

The ewes remained in yards for the period of progesterone injections, but were brought into a shearing shed on the day after the final progesterone injection (Day 1), where they remained until time of ovulation was ascertained. Water and food were offered $a d l i b$. in the shed.

\section{EXAMINATION OF OVARIES}

Laparotomy was conducted under local anaesthesia, with two laparotomy cradles (described by Lamond \& Urquhart, 1961). Before the first laparotomy each ewe was clipped in the inguinal region. The ewes were examined in random order. With two assistants, it was generally possible to examine the twenty-four ewes in each laparotomy group within $1 \mathrm{hr}$. The laparotomy incision, made anterior to the mammary gland and $\frac{1}{2}$ to $1 \mathrm{in}$. lateral to the midline, was re-opened at subsequent examinations.

For ovarian examination, the uteri and ovaries were brought to the exterior and the presence of large follicles, imminent ovulations and recent ovulations recorded. An ovulation was considered imminent when the smooth round surface of the follicle thinned out in one region and protruded to a point. Recent ovulations were classified into classes of 5-hr intervals. Hence, ovulations were recorded as taking place $20,25,30,35,40$ or more than $45 \mathrm{hr}$ after injection of HCG. Where more than one ovulation occurred, the time of the first was used in analyses of the results.

Since the operation intervals were 10 to $12 \mathrm{hr}$ it was only necessary to decide whether ovulations had occurred greater than or less than 5 to $6 \mathrm{hr}$ prior to the time of examination. In deciding the approximate time of ovulation, the following points were kept in mind:

(a) The state of the follicle was generally a poor guide since occasional follicles reached the pointing stage but did not ovulate. After some hours the fluid in the follicle became haemorrhagic in appearance and presumably premature luteinization took place.

(b) When the point of rupture exuded blood-stained fluid, ovulation was considered to have occurred within 5 to $6 \mathrm{hr}$ of examination.

(c) When the blood clot was firm (in some cases, rosette-shaped) and when gentle pressure resulted in only slight flow of serum, ovulation was considered to have occurred more than 5 to $6 \mathrm{hr}$.

(d) The initial assessment of time of ovulation was made without knowledge of the previous findings in each ewe. However, before each wound was sutured, an assistant described the previous results and the ovaries were re-examined, thus enabling a simple effective check of the classification method. 


\section{HORMONES}

Progesterone was dissolved at the concentration of $10 \mathrm{mg} / \mathrm{ml}$ in an oily solution comprising $100 \mathrm{ml}$ of ethyl oleate, $0.25 \mathrm{~g}$ of propyl gallate and arachis oil to $500 \mathrm{ml}$. A dose of $12.5 \mathrm{mg}$ of progesterone was injected intramuscularly every 2nd day at 9 to 9.30 a.m. This dose is sufficient to suppress oestrus and ovulation in a majority of ewes in May, which is near the peak of the breeding season (Lamond \& Lambourne, 1961). It is probably only slightly more than the minimum suppressive dose for that time of the year. At other times, it would be considerably greater than the minimum suppressive dose (Lamond, 1961), but since quantitative information was not available when the experiment commenced, the progesterone treatments were kept constant. During anoestrus, progesterone treatments may be considered as priming rather than suppressive.

The PMS used was a special batch of freeze-dried serum, kindly donated by Glaxo Ltd. The material contained 1200 nominal i.u./g, presumably based on ovarian weights in rats, which is the method recommended by the British Pharmacopoeia. However, when assayed on uterine weights of immature mice, the material had twice the nominal potency. The doses used in this experiment were 150 and 450 nominal units or 300 i.u. and 900 i.u. on the basis of the mouse uterine assay described by Claringbold \& Lamond (1957). The material was dissolved in distilled water immediately prior to use. Injections were made subcutaneously. The dried powder was stored in a refrigerator; there was no detectable loss of potency over the 12-month period.

The HaG was a purified preparation, 'Gonan' (British Drug Houses, Ltd), and was found to contain the labelled potency when tested by the mouse uterine assay. The material was dissolved in distilled water immediately prior to use and was injected intramuscularly. The doses employed were 300 i.u., 600 i.u. and 1200 i.u.

\section{RESULTS}

A total of sixteen ewes were eliminated from the results relating to time of ovulation. One contained a mummified foetus, one had an abdominal abscess and two others had swollen fluid-filled uteri. The remaining twelve evidently ovulated during the progesterone injections, since corpora lutea 4 to 12 days old were present at the time of laparotomy. The distribution of these ovulations was, July - two, October - five, January - nil, and April - five. These differences are not significant $\left(\chi^{2}(3)=6.3 ; 0.05<P<0.01\right)$.

Ovulation did not occur in twenty-eight ewes. Observations ceased approximately $60 \mathrm{hr}$ after HCG in the $24 \mathrm{hr}$ groups and approximately $45 \mathrm{hr}$ after HCG in the $48 \mathrm{hr}$ groups. In all these ewes, large follicles were observed at the first or second examination and in most instances they became larger (up to $2 \mathrm{~cm}$ diameter) but did not rupture. The numbers of ewes in each group that did not ovulate are shown in Tables 2 and 3. The data for January were analysed after transformation to angles. It is evident that a high proportion of ewes failed to ovulate in January in the 24-hr group receiving the two lower doses of HCG. In October the ewes which failed to ovulate all received 300 i.u. of PMS. 
TABLE 2

PROPORTION OF EWES NOT OVULATING AFTER HORMONE TREATMENT*

\begin{tabular}{|c|c|c|c|c|c|c|c|c|}
\hline \multirow{3}{*}{$\begin{array}{l}\text { PMS-HCG interval: } \\
\text { Dose of PMS (i.u.): } \\
\text { Dose of HCG (i.u.): }\end{array}$} & \multicolumn{4}{|c|}{$24 h r$} & \multicolumn{4}{|c|}{$48 \mathrm{hr}$} \\
\hline & \multicolumn{2}{|c|}{300} & \multicolumn{2}{|c|}{900} & \multicolumn{2}{|c|}{300} & \multicolumn{2}{|c|}{900} \\
\hline & 300600 & 1200 & 300600 & 1200 & 300600 & 1200 & 300600 & 1200 \\
\hline $\begin{array}{l}\text { July } \\
\text { October } \\
\text { January } \\
\text { April }\end{array}$ & $\begin{array}{ll}1 / 4 & 0 / 4 \\
0 / 4 & 1 / 4 \\
2 / 4 & 3 / 4 \\
2 / 3 & 0 / 4\end{array}$ & $\begin{array}{l}1 / 4 \\
1 / 4 \\
1 / 4 \\
0 / 2\end{array}$ & $\begin{array}{ll}1 / 4 & 0 / 4 \\
0 / 3 & 0 / 2 \\
3 / 4 & 2 / 4 \\
0 / 4 & 1 / 3\end{array}$ & $\begin{array}{l}1 / 4 \\
0 / 2 \\
0 / 4 \\
0 / 4\end{array}$ & $\begin{array}{ll}0 / 2 & 0 / 4 \\
2 / 2 & 0 / 4 \\
1 / 4 & 0 / 4 \\
0 / 4 & 0 / 4\end{array}$ & $\begin{array}{l}1 / 4 \\
2 / 4 \\
0 / 4 \\
0 / 4\end{array}$ & $\begin{array}{ll}1 / 4 & 1 / 4 \\
0 / 4 & 0 / 4 \\
0 / 4 & 0 / 4 \\
0 / 4 & 0 / 3\end{array}$ & $\begin{array}{l}0 / 4 \\
0 / 3 \\
0 / 4 \\
0 / 3\end{array}$ \\
\hline
\end{tabular}

* Ewes not ovulating within $60 \mathrm{hr}$ of HCG in 24-hr groups, and within $45 \mathrm{hr}$ of HGG in 48-hr groups.

\begin{tabular}{|c|c|c|}
\hline Source of variation & d.f. & Mean square \\
\hline $\begin{array}{l}\text { Times of HCG } \\
\text { Dose of PMS } \\
\text { Dose of HCG: Linear } \\
\text { Interactions } \\
\text { Euadratic }\end{array}$ & $\begin{array}{r}1 \\
1 \\
1 \\
1 \\
7 \\
\infty\end{array}$ & $\begin{array}{c}\text { January } \\
3675^{* * *} \\
300 \\
1378^{*} \\
84 \\
219 \\
205 \cdot 2\end{array}$ \\
\hline
\end{tabular}

TABLE 3

APPROXIMATE TIME (HR) OF OVULATION AFTER INJEGTION OF HCG IN INDIVIDUAL EWES

\begin{tabular}{|c|c|c|c|c|c|c|c|c|c|c|c|c|}
\hline \multirow{3}{*}{$\begin{array}{l}\text { PMS-HCG interval: } \\
\text { Dose PMS (i.u.): } \\
\text { Dose HGG (i.u.): }\end{array}$} & \multicolumn{6}{|c|}{$24 h r$} & \multicolumn{6}{|c|}{$48 \mathrm{hr}$} \\
\hline & \multicolumn{3}{|c|}{300} & \multicolumn{3}{|c|}{900} & \multicolumn{3}{|c|}{300} & \multicolumn{3}{|c|}{900} \\
\hline & 300 & 600 & 1200 & 300 & 600 & 1200 & 300 & 600 & 1200 & 300 & 600 & 1200 \\
\hline July 1960 & $\begin{array}{r}30 \\
35 \\
35 \\
>60\end{array}$ & $\begin{array}{l}25 \\
30^{*} \\
30 \\
30\end{array}$ & $\begin{array}{r}25 \\
25 \\
30 \\
>60\end{array}$ & $\begin{array}{r}25 \\
25 \\
30 \\
>60\end{array}$ & $\begin{array}{l}30 \\
30 \\
35^{*} \\
35\end{array}$ & $\begin{array}{r}25 * \\
25 \\
25 \\
>60\end{array}$ & $\begin{array}{l}20^{*} \\
20 \\
-\end{array}$ & $\begin{array}{l}25 \\
25 \\
25 \\
30\end{array}$ & $\begin{array}{r}20 \\
20 \\
25 \\
>45\end{array}$ & $\begin{array}{r}20 \\
25 \\
30 \\
>45\end{array}$ & $\begin{array}{r}15 \\
25 \\
30 \\
>45\end{array}$ & $\begin{array}{l}15 \\
20 \\
25 \\
25\end{array}$ \\
\hline October 1960 & $\begin{array}{l}30 \\
35 \\
35 \\
35\end{array}$ & $\begin{array}{r}25 \\
30 \\
30 \\
>60\end{array}$ & 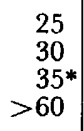 & $\begin{array}{l}30^{*} \\
30 \\
30 \\
-\end{array}$ & $\begin{array}{l}30 \\
35 \\
\\
\end{array}$ & $\begin{array}{l}25 \\
30 \\
- \\
-\end{array}$ & $\begin{array}{r}>45 \\
>45 \\
-\end{array}$ & $\begin{array}{l}20 * \\
20 \\
25 \\
25\end{array}$ & $\begin{array}{r}35 \\
35 \\
>45 \\
>45\end{array}$ & $\begin{array}{l}25^{*} \\
25^{*} \\
25 \\
30\end{array}$ & $\begin{array}{l}20^{*} \\
25^{*} \\
25 \\
25\end{array}$ & $\begin{array}{l}25^{*} \\
25 \\
25 \\
-\end{array}$ \\
\hline January 1961 & $\begin{array}{r}25 \\
30 \\
>60 \\
>60\end{array}$ & $\begin{array}{r}30 \\
>60 \\
>60 \\
>\end{array}$ & $\begin{array}{r}30 \\
30 \\
35 \\
>60\end{array}$ & $\begin{array}{r}25 \\
>60 \\
>60 \\
>60\end{array}$ & 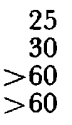 & $\begin{array}{l}30 \\
30 \\
30 \\
30\end{array}$ & $\begin{array}{r}25 \\
40 \\
40 \\
>45\end{array}$ & $\begin{array}{l}20 \\
25 \\
25 \\
25\end{array}$ & $\begin{array}{l}25^{*} \\
25^{*} \\
25 \\
25\end{array}$ & $\begin{array}{l}20 \\
25^{*} \\
30 \\
35\end{array}$ & $\begin{array}{l}15^{*} \\
25 \\
25 \\
30\end{array}$ & $\begin{array}{l}15 \\
15 \\
25 \\
30\end{array}$ \\
\hline April 1961 & 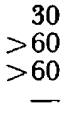 & $\begin{array}{l}30 \\
30 \\
30 \\
40\end{array}$ & $\begin{array}{l}30 \\
30 \\
- \\
-\end{array}$ & $\begin{array}{l}20 \\
25 * \\
30 \\
35\end{array}$ & $\begin{array}{r}25 \\
40 \\
>60 \\
\end{array}$ & $\begin{array}{l}15 \\
25^{*} \\
25 \\
25\end{array}$ & $\begin{array}{l}25 \\
25 \\
30 \\
30\end{array}$ & $\begin{array}{l}25 \\
25 \\
25 \\
30^{*}\end{array}$ & $\begin{array}{r}25 \\
30 \\
30 \\
+\quad 40\end{array}$ & $\begin{array}{l}25^{*} \\
25 \\
25 \\
25\end{array}$ & $\begin{array}{l}20 \\
20 \\
25 \\
-\end{array}$ & $\begin{array}{l}20 \\
20 \\
30 \\
-\end{array}$ \\
\hline
\end{tabular}

- Two ovulations; the second ovulation occurred at the same time or up to $10 \mathrm{hr}$ later than the first. $>45,>60=$ Ewes not ovulated at the time of the final ovarian examination.

$-=$ Ewes eliminated from the results. 
TIME OF OVULATION

The time of ovulation in each ewe in the experiment is shown in Table 3. Ewes not ovulating at the time of the final laparotomy are also included and are prefixed by a > sign, for convenience. For the purpose of preliminary analysis, ewes that did not ovulate were given an arbitrary time of ovulation of $45 \mathrm{hr}$, thus enabling a more reasonable statistical evaluation of the data than would be the situation were these ewes discarded. The mean times of ovulation by

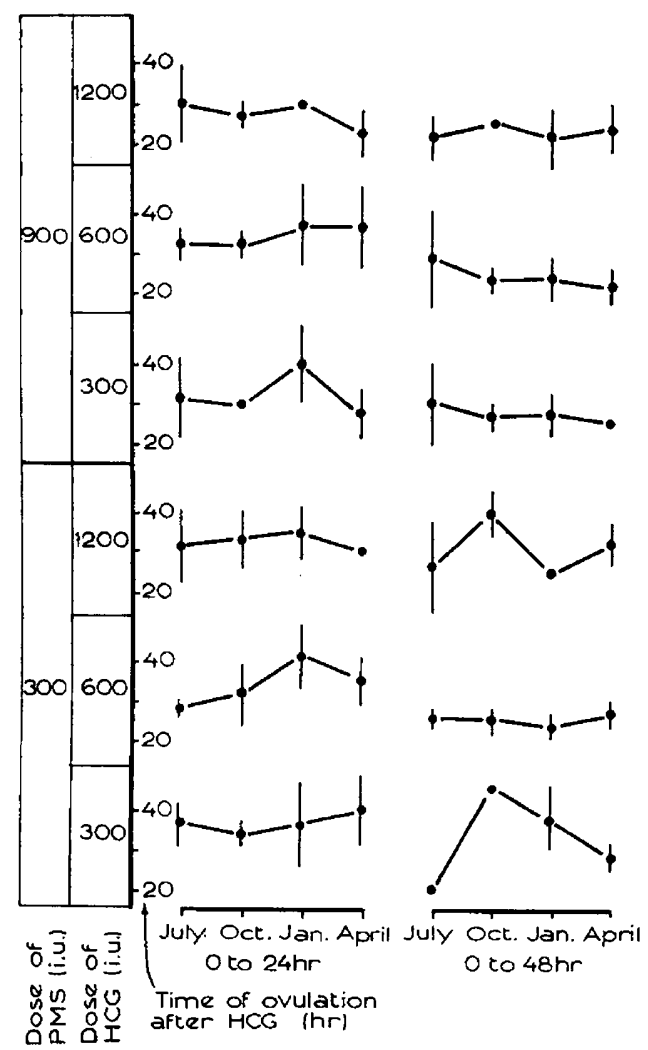

TEXT-FIG. 2. Mean time of ovulation ( \pm s.E.) after injection of HCG; PMS given at time of final progesterone injection; HCG given 24 and 48 hr after PMs. Four sheep per group.

this approximation are presented in diagram form in Text-fig. 2. The following are the main results:

In July and April ovulation occurred 20 to $30 \mathrm{hr}$ after HCG when the interval from PMS to HCG was $48 \mathrm{hr}$. There were no obvious differences related to dosage levels of PMS or HCG. When the PMS-HGG interval was $24 \mathrm{hr}$, ovulation occurred 25 to $35 \mathrm{hr}$ after the HCG, the greatest delay being in the low PMSlow HCG treatment.

Times of ovulation following 900 i.u. PMs were uniform in October. The period from HCG to ovulation, regardless of dose of HCG, was $25 \mathrm{hr}$ for the PMS-HCG interval of $48 \mathrm{hr}$ and $30 \mathrm{hr}$ for the PMS-HCG interval of $24 \mathrm{hr}$. With 300 i.u. 
PMS doses the results for 600 i.u. HCG followed the same pattern, but those for 300 i.u. and 1200 i.u. HGG did not. At the latter two doses, ovulations were delayed considerably when the PMS-HCG interval was $48 \mathrm{hr}$.

In January, ovulations after the PMS-HCG interval of $48 \mathrm{hr}$ were generally uniform except for low PMs-low HcG. When the gonadotrophin interval was 24 $\mathrm{hr}$ the proportion of ewes not ovulating was too high to enable a reasonable estimate of the differences between times of ovulation.

In general, when the interval from PMS-HCG was $24 \mathrm{hr}$, results were more variable than when following the 48-hr interval, for both within- and betweentimes of the year. When the interval was $48 \mathrm{hr}$, the times of ovulation were generally uniform particularly following 300 i.u. PMs to 600 i.u. HCG. Differences between doses within-times of the year were negligible except for October.

TABLE 4

OCGURRENGE OF MULTIPLE OVULATIONS IN EWES*

(NOT INCLUDING EWES ELIMINATED FROM RESULTS)

\begin{tabular}{l|c|c|c|c}
\hline PMS-HCG interval: & \multicolumn{2}{|c|}{$24 h r$} & \multicolumn{2}{|c}{$48 h r$} \\
\hline Dose PMs (i.u.): & 300 & 900 & 300 & 900 \\
\hline July 1960 & $1 / 12$ & $2 / 12$ & $1 / 10$ & $0 / 12$ \\
October 1960 & $1 / 12$ & $1 / 7$ & $1 / 10$ & $5 / 11$ \\
January 1961 & $0 / 12$ & $0 / 12$ & $2 / 12$ & $2 / 12$ \\
April 1961 & $0 / 9$ & $2 / 12$ & $2 / 12$ & $1 / 10$ \\
\hline
\end{tabular}

* HCG data within above treatment combinations pooled to save space. A preliminary analysis indicated that there was no effect due to dose of HCG.

MULTIPLE OVULATIONS

The occurrence of multiple ovulations (two ovulations in twenty ewes; three in one ewe) is set out in Table 4. There were no significant differences between treatments. In a group of forty normal cycling Merino ewes examined by laparotomy in May 1961, six (15\%) had double ovulations. This is probably an accurate estimate of multiple ovulations in the strain of ewes on the Research Station since 5 to $10 \%$ bear twins following a May joining.

\section{DISGUSSION}

There were no significant differences between four times of the year in the number of ovulations occurring during progesterone treatment. The four times of examination did not include the mid-points of the breeding season and anoestrus but should nevertheless have shown seasonal differences had they been important.

The incidence of multiple ovulations did not follow the pattern generally observed in normal ewes. Thus Radford (1959) observed that multiple ovulations were high in the breeding season, particularly the mid-breeding season, and low in anoestrus. The increase in numbers of multiple ovulations in October and January in this experiment is possibly related to the observations of 
Robinson (1950) and Gordon (1958) that the number of ovulations increases slowly with increasing doses of PMS up to a point when the relationship suddenly alters so that for small increases in dose, large increases in numbers of ovulations occur. The doses of PMS used in the experiment were evidently not superovulatory, but may have been effective in raising the proportion of multiple ovulations during anoestrus to levels comparable with that seen during the breeding season, i.e. the doses were near the lower asymptote of the doseresponse curve.

A high proportion of ewes failed to ovulate in January when HCG was given $24 \mathrm{hr}$, but not when given $48 \mathrm{hr}$, after pMs. This seems to indicate that one aspect of the seasonal difference in pituitary-ovarian function is the sensitivity of the neural-endocrine system controlling ovarian activity. Seasonal differences in suppressive action of progesterone have been observed by Lamond (1961) and Lamond \& Bindon (1962). During January, the suppressive action of the dose of progesterone used in this experiment was probably greater than at the other times, resulting in a depressed response to injected gonadotrophin.

Ovulations were induced at all times of the year. The times of ovulation throughout the year were extremely uniform in the 300 i.u. PMS to 600 i.u. HCG treatments when the PMS-HCG interval was $48 \mathrm{hr}$. In general PMS-HCG intervals of $48 \mathrm{hr}$ gave satisfactory results except in October. The October results are difficult to explain, but are in agreement with earlier findings (Lamond, 1960). Thus though inexplicable at present, the October results cannot be described as fortuitous.

Nevertheless, it is apparent that by selecting the correct PMS-HCG dose interval regime ovulation can be induced regularly throughout the year. These findings, therefore, extend those of Braden, Lamond \& Radford (1960). The full significance of the use of a constant dose of progesterone at the four times of the year remains to be determined. The question of seasonality in ovulating hormone production or total gonadotrophin production should be reconsidered on the basis of these findings and those of Lamond (1961) and Lamond \& Bindon (1962). As measured by ovulation rates, occurrence of oestrus and other factors outlined in the Introduction and from the results of the present experiment, there are unquestionably seasonal differences in pituitary-ovarian activity. A more useful approach to seasonality in sheep breeding than measurement of hormone production may be to examine the sensitivity of the neuro-hormonal complex to hormones, particularly to progesterone and oestrogen.

\section{ACKNOWLEDGMENTS}

Thanks are due to colleagues of the Division of Animal Physiology, C.S.I.R.O., for valuable criticisms and comments during preparation of the manuscript.

\section{REFERENCES}

AveriLl, R. L. W. (1955) Fertility of the ewe. Studies on Fertility, Vol. 7, p. 139. Blackwell Scientific Publications, Oxford.

Averill, R. L. W. (1959) Ovulatory activity in mature Romney ewes in Otago. N.Z. F. agric. Res. 2, 575 . 
Barrett, J. F., Reardon, T. F. \& Lambourne, L. J. (1962) Seasonal variation in reproductive performance of Merino ewes in Northern New South Wales. Submitted to Aust. F. exp. Agr. Anim. Husb. 2, (5) [in press].

BRADEN, A. W. H., LAMOND, D. R. \& RADFord, H. M. (1960) The control of the time of ovulation in sheep. Aust. 7. agric. Res. 11, 389.

Glaringbold, P. J. \& Lamond, D. R. (1957) Optimum conditions for the biological assay of gonadotrophins. F. Endocrin. 16, 86.

Clegg, M. T. \& Ganong, W. F. (1960) The effect of hypothalamic lesions on ovarian function in the ewe. Endocrinology, 67, 179.

Dun, R. B., Ahmed, Waheed \& Morrant, A. J. (1960) Annual reproductive rhythm in Merino sheep related to the choice of mating time at Trangie, Central Western New South Wales. Aust. $\mathcal{F}$. agric. Res. 11, 805.

Dutr, R. H. (1951) Fertility rate and embryonic death loss in ewes early in the breeding season. F. Anim. Sci. 10, 1075.

Grant, R. (1934) Studies on the physiology of reproduction in the ewe. Trans. roy. Soc., Edinb. 58, 1.

Gordon, I. (1958) The use of progesterone and serum gonadotrophin (PMS) in the control of fertility in sheep. I. The hormonal augmentation of fertility in the ewe during the breeding season. 7. agric. Sci. 50, 123.

Hafez, E. S. E. (1952) Studies on the breeding season and reproduction of the ewe. I. The breeding season in different environments. II. The breeding season in one locality. F. agric. Sci. 42, 189.

Hammond, J., JNR. (1944) On the breeding season in the sheep. J. agric. Sci. 34, 97.

Hulet, G. V., Voigtlander, H. P., Jnr., Pope, A. L. \& Gasida, L. E. (1956) The nature of earlyseason infertility in sheep. 7. Anim. Sci. 15, 607.

Hunter, G. L. (1959) A contribution to the study of the problem of low fertility among Merino ewes in South Africa. 7. agric. Sci. 52, 282.

Hutchinson, J. S. M. \& Robertson, H. (1960) Effect of season on the follicle stimulating hormone and luteinizing hormone potency of sheep anterior pituitary glands. Nature, Lond. 188, 585.

Kammlade, W. G., Welch, J. A., Nalbandov, A. V. \& Norton, H. W. (1952) Pituitary activity of sheep in relation to the breeding season. F. Anim. Sci. 11, 646.

LAFFEY, N. \& HART, D. S. (1959) Embryonic loss from late breeding season mating of ewes. $\mathcal{N} . Z \cdot \mathcal{F}$. agric. Res. 2, 1159.

Lamond, D. R. (1960) Seasonal differences in ovulating hormone in the Merino ewe. Nature, Lond. $186,971$.

Lamond, D. R. (1962) Suppression of ovarian cycles in sheep using progesterone. Proc. Conf. A.I. Sheep. Univ. New South Wales. [In press.]

Lamond, D. R. \& Lambourne, L. J. (1961) Suppression of oestrus in sheep with progesterone. Aust. 7. agric. Res. $12,154$.

Lamond, D. R. \& Urquharr, E. J. (1961) Sheep laparotomy cradle. Aust. vet. 7. 37, 430.

LAMOND, D. R. \& Bindon, B. M. (1962) Oestrus, ovulation and fertility following progesterone suppression of ovarian cycles in Merino ewes. 7. Reprod. Fertil. 4, 57.

LAMOND, D. R., RAdFord, H. M. \& WAllace, A. L. (1959) Bioassay of sheep anterior pituitary glands. Nature, Lond. 183, 1597.

McKenzie, F. F. \& Terrill, G. E. (1937) Estrus, ovulation and related phenomena in the ewe. Res. Bull. Mo. agr. exp. Sta. No. 264.

Morley, F. H. W. (1948) Some seasonal factors affecting fertility among Merino ewes in the Trangie district of New South Wales. Aust. vet. 7. 24, 106.

RADFORD, H. M. (1959) Variation in the incidence of twin ovulation in Merino ewes on a constant plane of nutrition. Aust. 7. agric. Res. 10, 377.

RAEside, J. I. \& LAMOND, D. R. (1956) Effects of progesterone and pregnant mare serum (PMs) administration in the anoestrous ewe. I. Oestrus, ovarian changes, and gonadotrophic potency of the pituitary gland. Aust. 7. agric. Res. 7, 591 .

Raeside, J. I. \& McDonald, M. F. (1959) Seasonal changes in the oestrus response by the ovariectomized ewe to progesterone and oestrogen. Nature, Lond. 184, 458.

Reardon, T. F. \& Robinson, T. J. (1961) Seasonal variation in the reactivity to oestrogen of the ovariectomized ewe. Aust. 7. agric. Res. 12, 320.

Riches, J. H. \& WAtson, R. H. (1954) The influence of the introduction of rams on the incidence of oestrus in Merino ewes. Aust. 7 . agric. Res. 5, 141.

Robinson, T. J. (1950) The control of fertility in sheep. I. Hormonal therapy in the induction of pregnancy in the anoestrous ewe. 7 . agric. Sci. 40, 275.

Robinson, T. J. (1951) Reproduction in the ewe. Biol. Rev. 26, 121.

Watson, R. H. (1952) Seasonal variation in reproductive activity in ewes. Aust. vet. $7.28,1$.

WARwICK, E. G. (1946) Gonadotrophic potency of ewe pituitary glands as affected by spaying, season, and breed. Proc. Soc. exp. Biol., N.Y. 63, 530. 